\title{
Keseimbangan Relasi Orang Tua-Remaja sebagai Prediktor Kejelasan Orientasi Masa Depan Pendidikan
}

\author{
Awit Marwati Sakinah \\ STMIK Tasikmalaya, J1. R.E Martadinata No.272 A \\ e-mail: awitsakinah@gmail.com
}

\begin{abstract}
Future orientation is formed as a result of interaction with the environment one of them teenage parents. The study aims to determine the effect balance relationship patterns of parentadolescent to the orientation of future education in adolescents of Bandung city. The analysis technique used is the correlation analysis and logistic regression. The study use cluster sampling to obtain a sample of 358 students. The results showed that the balance relations on the dimensions of adaptability and cohesion have a greater influence on the clarity of the future orientation of youth education in Bandung. Balance relationship patterns of parentadolescent balance has possibility of 16.181 times more clearly educational future compared with the balance of relationship patterns of parent-adolescent unbalance. Balance relationship patterns of parent-adolescent has possibility of 2.088 times more clearly educational future compared with the balance of relationship patterns of parent- adolescent to mid range category.
\end{abstract}

Keywords: future orientation, balance pattern of relations, adolescent, education

\begin{abstract}
Abstrak
Orientasi masa depan (OMD) terbentuk sebagai hasil interaksi remaja dengan lingkungan, salah satunya adalah orang tua. Penelitian ini bermaksud untuk mengetahui pengaruh keseimbangan relasi orang tua-remaja terhadap OMD pendidikan pada remaja di kota Bandung. Penelitian ini menggunakan pendekatan kuantitatif. Teknik analisis yang digunakan adalah analisis korelasi dan regresi logistik. Teknik sampling menggunakan cluster sampling dengan sampel sebanyak 358 siswa. Hasil penelitian menunjukkan bahwa relasi orang tuaremaja yang seimbang pada dimensi adaptabilitas dan kohesi memiliki pengaruh yang lebih besar pada kejelasan OMD pendidikan remaja di kota Bandung. Keseimbangan relasi orang tua-remaja yang balance memiliki kemungkinan sebesar 16,181 kali untuk memiliki OMD pendidikan yang jelas dibandingkan dengan keseimbangan pola relasi orang tua-remaja yang unbalance. Keseimbangan pola relasi orang tua-remaja yang balance memiliki kemungkinan 2,088 kali untuk memiliki OMD pendidikan yang jelas dibandingkan dengan keseimbangan pola relasi orang tua-remaja dengan kategori mid range.
\end{abstract}

Kata Kunci: orientasi masa depan, keseimbangan relasi, remaja, pendidikan, orang tua

\section{Pendahuluan}

Sejarah telah banyak mencatat bahwa orang-orang yang sukses adalah mereka yang mempunyai tujuan hidup di masa depan dan membuat langkah-langkah perencanaan untuk dapat mencapai tujuan hidupnya tersebut. Mereka yang tidak mempunyai mimpi atau tujuan hidup beserta perencanaanya akan merasa bingung dan hanya mengikuti arus kehidupan. Hal ini sejalan dengan apa yang diungkapkan oleh Nurmi (1991) bahwa secara umum, pikiran dan tingkah laku manusia mengarah pada kejadian dan hasil yang nanti akan didapatkanya. Apa yang akan terjadi dimasa depan, memotivasi seseorang untuk melakukan tingkah laku tertentu.

Dalam kenyataanya, tidak sedikit orang yang seolah membiarkan kehidupan mereka berjalan seperti air mengalir. Mereka memiliki prinsip bahwa hidup harus dijalani sebagaimana adanya. Me- 
mikirkan masa depan dan membuat perencanaan pencapaian bukan menjadi suatu hal yang diprioritaskan. Di sisi lain, era globalisasi menuntut individu untuk bisa menjadi seorang yang berprestasi, kompeten, dan mampu bertahan ditengah persaingan yang semakin ketat.

Pembentukan tujuan masa depan sudah dimulai ketika individu mencapai tahap remaja awal di mana ia mulai membentuk kemampuan untuk me-rencanakan sesuatu di masa depan. Menurut Santrock (2003) batasan usia remaja dibagi menjadi 10-12 tahun, 13-17 tahun dan 18-21 tahun. Perencanaan masa depan seperti pendidikan, karir, pernikahan mulai muncul dalam pemikiran individu ketika ia mencapai usia 10-11 tahun (Nurmi, 1991).

Keputusan yang harus diambil terkait masa depan khususnya dalam bidang pendidikan akan berpengaruh terhadap perkembangan kepribadian selanjutnya (Nurmi, 1991). Sebagaimana dikatakan oleh Havinghurst (dalam Nurmi, 1994) bahwa keberhasilan seseorang dalam menyelesaikan tugas perkembangan akan menjadi dasar bagi penyelesaian tugas perkembangan selanjutnya. Mereka yang berhasil menyelesaikan tugas perkembangan akan berkembang menjadi individu yang bahagia dan cenderung akan sukses pada tugas perkembangan berikutnya.

Orientasi masa depan menentukan bagaimana seseorang merumuskan dan menyusun visi ke depan dengan membagi orientasi jangka pendek, menengah, dan jangka panjang (Agustian \& Ginanjar, 2001), sehingga berhubungan dengan bagaimana seseorang berfikir maupun bertingkah laku menuju masa depan.

Seiring bertambahnya usia, remaja akan semakin tertarik pada tugas-tugas perkembangannya seperti pendidikan, perkerjaan dan keluarga (Sundberg et al., dalam Nurmi, 1989), dan pada umumnya remaja yang memasuki tahap remaja akhir mulai mengantisipasi masa depan mereka terutama pada bidang pendidikan yang akan mereka jalani.
Nurmi (1989) mendefinisikan orientasi masa depan sebagai tiga rangkaian proses yakni motivasi (motivation), perencanaan (planning), dan evaluasi (evaluation) yang berinteraksi dengan skema kognitif. Proses motivasi mengacu pada minat dan tujuan individu di masa depan, sedangkan proses perencanaan mengacu pada bagaimana seseorang merencanakan perwujudan minatnya. Adapun proses evaluasi memfokuskan pada sejauh mana seseorang berharap agar minatnya dapat terwujud.

Locke dan Lathman (1990) melaporkan banyak hasil penelitian yang menyimpulkan bahwa perilaku yang diarahkan oleh tujuan (goal directed behavior) lebih efektif dibandingkan dengan perilaku yang tidak diarahkan oleh tujuan. Seseorang yang memiliki tujuan yang jelas, akan lebih memfokuskan dirinya untuk melakukan hal-hal yang hanya berhubungan dengan apa yang ingin dicapainya.

Proses orientasi masa depan berhubungan dengan beberapa tiga faktor pentimg. Pertama tujuan dan standar pribadi menjadi dasar bagi individu untuk melakukan evaluasi terhadap dirinya. Pencapaian tujuan akan membentuk suatu konsep diri yang positif dan keyakinan akan kemampuan diri. Kedua, efektifitas perencanaan yang telah dibuat akan mempengaruhi pencapaian tujuan yang diinginkan. Ketiga, hasil evaluasi individu yang mempengaruhi konsep dirinya akan mempengaruhi tujuan yang ditetapkan kemudian. (Bandura dalam Nurmi 1994).

Orientasi masa depan terbentuk sebagai hasil interaksi individu dengan lingkungannya, salah satu faktor lingkungan yang berperan penting adalah lingkungan keluarga (Nurmi, 1991). Mampu atau tidaknya remaja membuat keputusan secara dini mengenai tujuan pendidikan di masa depannya, dapat atau tidaknya remaja menyusun serta menjalankan strategi untuk mencapai tujuan pendidikannya, dapat atau tidak ia mengevaluasi kemungkinan/ peluang untuk 
mencapai tujuan di masa depan pendidikannya tergantung dari bagaimana orang tua berhubungan dalam membina, mendidik dan mengarahkan anak-anaknya (Afrianti, 2016)

Nurmi (1989) mengatakan bahwa ketika keadaan masa depan beserta faktor pendukungnya telah menjadi sesuatu yang diharapkan dapat terwujud maka pengetahuan yang menunjang untuk terwujudnya harapan tersebut menjadi dasar penting dalam orientasi masa depan. Terbatasnya pengalaman dan pengetahuan yang dimiliki oleh remaja mengenai pendidikan mengakibatkan mereka masih membutuhkan bimbingan dan dukungan dari orang tua mereka. Orang tua dapat dijadikan sebagai role model bagi remaja untuk menentukan minat mereka, sehingga pengetahuan tentang strategi penyelesaian hambatan yang akan mereka hadapi saat mewujudkan minat mereka nantinya dapat teratasi. Dukungan orang tua juga berhubungan dengan optimisme dan internalitas remaja dalam menghadapi masa depan mereka (Pulkinen et,al, dalam Nurmi, 1989).

Dengan adanya dukungan orang tua atas keputusan dan rencana yang disusun oleh remaja dapat tercermin dari berbagai perlakuan yang diberikan oleh orang tua kepada anak mereka. Misalnya saja, memberikan masukan-masukan mengenai pilihan mana yang terbaik, serta mengawasi segala usaha yang dilakukan oleh anaknya dalam meraih pendidikan yang telah dipilihnya di masa depan. Untuk menunjukan penghargaan kepada anak, orang tua dapat memberikan kepercayaan kepada anak mereka untuk memilih bidang studi yang mereka sukai setelah lulus SMA/SMK.

Nurmi (1994) mengungkapkan 2 faktor utama yang mempengaruhi orientasi masa depan, yaitu faktor individual dan faktor kontekstual. Pertama adalah faktor individual. Orientasi masa depan merupakan suatu proses yang berlangsung di dalam sistem kognisi remaja. Menurut
Nurmi (1994), faktor-faktor psikologis mempengaruhi perkembangan orientasi masa depan. Seperti halnya peningkatan kemampuan kognitif mempengaruhi kemampuan remaja untuk menentukan tujuan, menyusun rencana dan mencari jalan yang paling efektif untuk mencapai tujuan tersebut ataupun mencari alternatif lain jika perencanaan tersebut mengalami perubahan.

Kedua adalah faktor kontekstual. Remaja tidak dapat dipisahkan dari lingkungannya. Segala sesuatu yang diterima remaja dari lingkungan akan mempengaruhi pengetahuan dan pandangan mereka ke masa depan. Kesempatan yang diberikan lingkungan akan mempengaruhi wawasan pengetahuan remaja yang berperan dalam perkembangan orientasi masa depan. Lingkungan khusus di mana remaja tinggal juga berpengaruh terhadap perkembangan pemikiran remaja kearah masa depan.

Selain itu didikan orang tua terhadap remaja memberikan keterampilan dasar bagi remaja dalam mempersiapkan masa depannya. Selanjutnya dorongan dan model tingkah laku dari orang tua mempengaruhi cita-cita dan rencana remaja dimasa depan.

Orang tua memegang peranan penting melalui relasi yang diterapkan pada anak mereka dalam proses menentukan keberhasilan pembentukan orientasi masa depan. Orang tua mempengaruhi orientasi masa depan anak mereka dalam 3 hal, pertama, standar normatif yang ditetapkan orang tua mempengaruhi minat, penilaian dan cita-cita remaja (Conger 1975; dalam Nurmi 1994). Kedua, contoh yang diberikan orang tua dalam menyelesaikan tugas perkembangan membuat remaja cenderung melakukan tindakan yang sama dalam menyelesaikan tugas perkembangannya. Ketiga, atribusi kausal yang dikembangkan orang tua membuat remaja memiliki atribusi yang sama.

Selain itu menurut penelitian Trommsdroff (dalam McCabe \& Bernet, 2000) menemukan bahwa remaja yang 
mendapatkan dukungan dan keterbukaan dari orang tua mereka cenderung memiliki orientasi masa depan yang lebih positif dibandingkan dengan remaja yang kurang mendapatkan dukungan dari orang tua mereka.

Dengan demikian Remaja yang mendapatkan kasih sayang dan dukungan dari orang tuanya akan mengembangkan rasa percaya dan sikap yang positif terhadap masa depan, percaya akan keberhasilan yang dicapainya, serta lebih termotivasi untuk mencapai tujuan yang telah dirumuskan. Sebaliknya, remaja yang kurang mendapat dukungan dari orang tua, akan tumbuh menjadi individu yang kurang optimis, kurang memiliki harapan tentang masa depan, kurang percaya atas kemampuan mereka dalam merencanakan masa depan, dan memiliki pemikiranya yang kurang sistematis dan terarah.

Relasi yang dibangun antara orang tua dan remaja akan membentuk pola tertentu (dalam Wibowo, 2004). Relasi antara orang tua dengan remaja dibangun sejak awal kehidupan remaja tersebut. Menurut Olson (1993) terdapat dua dimensi yang menggambarkan pola relasi keluarga yaitu dimensi kohesi dan dimensi adaptabilitas. Dimensi kohesi merupakan kedekatan emosional antar anggota keluarga. Dimensi adaptabilitas merupakan kemampuan keluarga dalam menyesuaikan aturan-aturannya sesuai dengan perubahan situasi yang dihadapi. Penghayatan interaksi antara orang tua dan remaja tergambar melalui kedua dimensi tersebut.

Dimensi kohesi dibangun oleh: 1) adanya intensitas kebersamaan yang dihayati dalam separateness atau togetherness; 2) tanggung jawab yang dihayati apakah reamaja lebih pada diri sendiri atau orang tua ( $I v s W e) ; 3$ ) kedekatan dan perhatian antara orang tua- remaja (closeness); 4) menghormati dan membela keluarga (loyalty); dan 5) ketergantungan emosi (dependency/ independency).

Individu yang mengalami empat derajat kohesi dalam hubungannya dengan orang lain, termasuk juga dengan anggota keluarga. Keempat derajat kohesi ini oleh Olson disebut disengaged, separated, connected, enmeshed, yang secara berturutturut menunjukkan kedekatan hubungan yang secara emosional ekstrim jauh sampai ekstrim dekat, untuk derajat ekstrim tinggi disebut disengaged, dan untuk ekstrim rendah disebut enmeshed. Derajat kohesi ekstrim rendah (disengaged) ataupun ekstrim tinggi (enmeshed) merupakan karakteristik hubungan yang cenderung akan menimbulkan permasalahan. Meskipun pola relasi disengaged maupun enmeshed cocok untuk saat-saat tertentu, hubungan semacam itu akan bermasalah bila keluarga terperangkap dalam area tersebut. Sedangkan derajat kohesi yang separated dan connected merupakan corak hubungan yang paling fungsional sepanjang daur kehidupan, karena hubungan tersebut mampu menyeimbangkan antara separateness dan togetherness. Oleh karena itu hubungan-hubungan ini disebut "seimbang". Pasangan yang merasa nyaman dengan relasi mereka dan berfungsi baik menurut penilaian para ahli, cenderung merupakan pasangan yang berada di tengah peta relasi.

Dimensi kedua adalah dimensi adaptabilitas yang dibangun oleh: 1) perubahan-perubahan dalam peraturan, peran perlakukan orang tua terhadap remaja (change); 2) gaya kepemimpinan yang diterapkan orang tua (leadership); 3) konsistensi pelaksanaan peraturan (discipline); dan 4) seberapa sering orang tua dan remaja dapat berubah dalam menjalankan perannya (roles). 


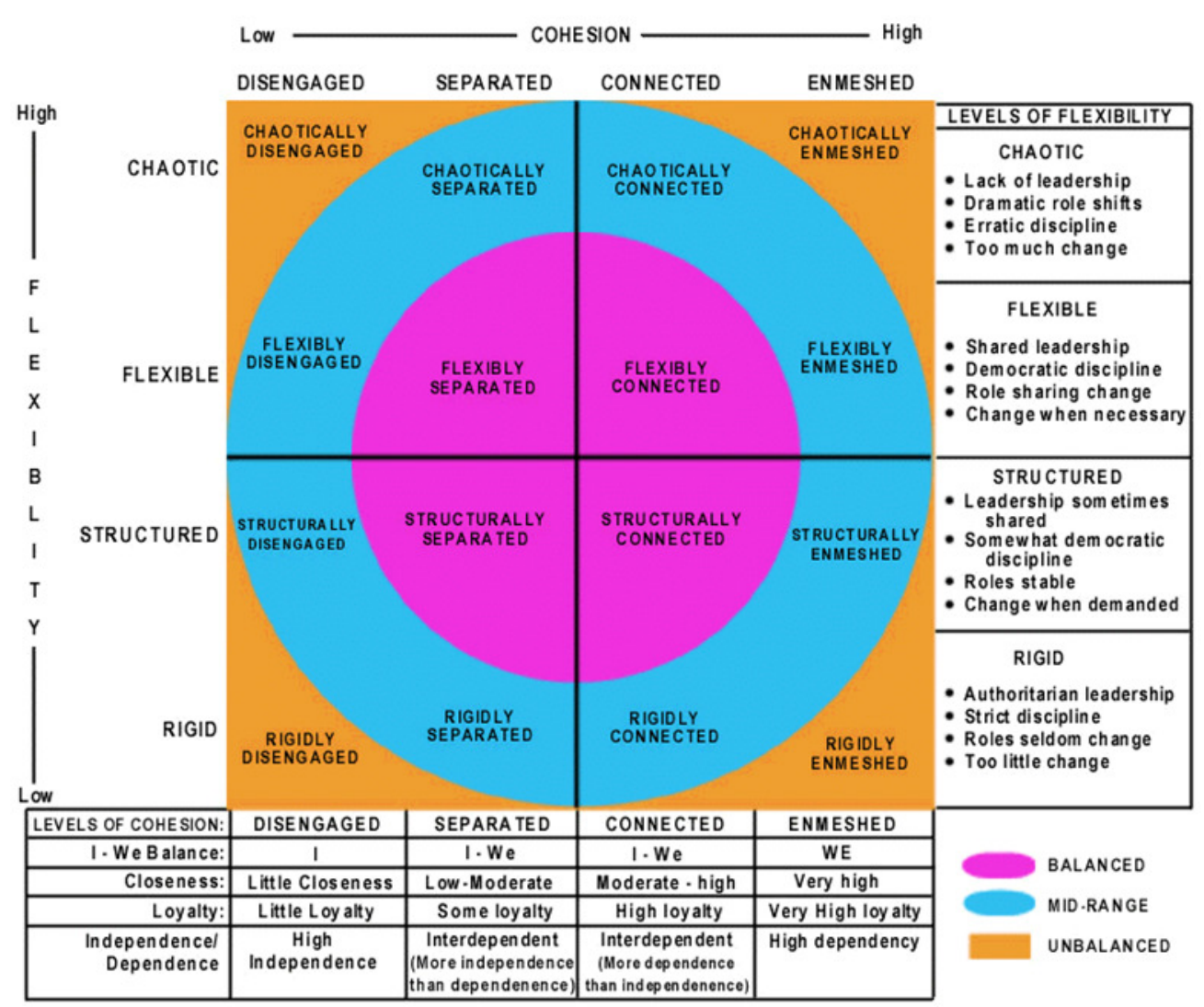

Gambar 1.

Sama halnya dengan kohesi, adaptabilitas memiliki empat derajat yang terentang dari ekstrim rendah (rigid), sampai ekstrim tinggi (chaotic). Di antara kedua ekstrim tersebut terdapat derajat structured dan flexible. Kedua area adaptabilitas yang ekstrim ini bersifat tidak seimbang, akan memunculkan masalah bagi para anggotanya, sedangkan pada derajat structures dan flexible memiliki sifat seimbang (balanced).

Rigid, merupakan keluarga yang secara ekstrim membuat keputusan dengan negosiasi yang dibatasi dan peraturan serta peran masing-masing anggota keluarga yang dijelaskan dan dipatuhi. Structured yaitu sistem kepemimpinan yang bercampur antara authoritarianequalitarian sehingga menciptakan peraturan dan peran yang stabil. Sedangkan fleksibel merupakan keluarga yang menggunakan kepemimpian equalitarian di mana persetujuan berdasarkan negosiasi
Circumplex Model

dibuat sehingga mudah dalam mengganti peran dan peraturan. Chaotic adalah keluarga yang memiliki kepemimpinan tidak efektif dan tidak menentu yang cenderung menghasilkan keputusan impulsif, peraturan yang tidak konsisten, dan peran yang dapat berubah. (Olson, Russel, \& Sprengkle, 1989)

Bertumpu pada dimensi kohesi dan adaptabilitas, Olson dkk (1989) membuat model relasi keluarga (orang tua-remaja) yang disebut dengan circumplex model, yang digambarkan dalam peta relasi. Perpaduan kedua dimensi itu masingmasing menghasilkan 4 kategori dari yang ekstrim tinggi (1 kategori), ekstrim rendah (1 kategori) dan rata-rata (2 kategori) di mana akan menghasilkan 16 tipologi pola relasi: chaotically disengaged, chaotically separated, chaotically connected, chaotically enmeshed, flexible disengaged, flexible separated, flexible connected, flexible 
enmeshed, structurally disengaged, structurally separated, structurally connected, structurally enmeshed, rigidly disengaged, rigidly separated, rigidly connected, rigidly enmeshed. Pada akhirnya formulasi pola relasi ini akan menentukan keberfungsian dalam keluarga pada taraf balanced, midrange dan extremel unbalanced.

Individu perlu menyeimbangkan kohesi dan adaptabilitas pada kedua sisi ekstrimnya. Keluarga yang berfungsi dengan baik sepanjang siklus kehidupan mampu menyeimbangkan antara derajat keterpisahan dan kebersamaan sehingga mereka mempunyai beberapa komponen dari masing-masing. Hal tersebut menyebabkan kemampuan untuk terpisah dan bertindak secara otonomi sebagai individu tetapi pada waktu lain dapat menjadi dekat dan intim dan mampu stabil dalam perubahan.

Keadaan seimbang pada kedua dimensi mempunyai arti bahwa keluarga dapat saja mengalami sisi ekstrim dari dimensi-dimensi tersebut jika memang keadaannya tepat, tetapi tidak berfungsi pada sisi ekstrim tersebut dalam jangka waktu yang lama. Keluarga yang memiliki tipe relasi balanced mampu membiarkan anggota keluarganya untuk merasa bebas dan dekat dengan keluarga mereka. Kedua sisi ekstrim dapat ditoleransi dan dihargai, tetapi keluarga tidak berfungsi secara terus menerus pada kedua sisi ekstrim tersebut. sebaliknya, keluarga yang ekstrim menurut model circumplex ini cenderung untuk berfungsi hanya pada sisi ekstrim dan akan terkesan terpaku di sana.

Hal lain yang perlu diperhatikan yaitu adanya sebuah keseimbangan yang dinamis, yang diartikan bahwa perubahan pada kedua dimensi dapat terjadi pada relasi pasangan dan keluarga. Misalnya, ketika sebuah keluarga yang seimbang (secara struktur terhubung) berada di bawah tekanan stres, hal tersebut mungkin mengubah sistem keluarganya menjadi lebih flexible enmesh. Tipe ini mungkin dapat membantu anggotanya menyelesaikan secara efektif sumber stres yang ada. Seiring dengan berjalannya waktu dan stres mengalami penurunan, sistem keluarga biasanya kembali ke bentuk sebelumnya. Keseimbangan yang dinamis ini juga dapat terjadi karena sistem keluarga yang berubah selama keluarga tersebut mengalami perkembangan sepanjang siklus kehidupan keluarga.

Adanya konsep keseimbangan pada curvilinear antara kohesi dan adaptabilitas memperlihatkan bahwa keluarga mempunyai skor yang rendah sekali atau tinggi sekali dari dimensi-dimensi ini cenderung lebih disfungsional, atau tidak sehat. Sebuah relasi linear berarti semakin tinggi skor kohesi atau semakin tinggi skor adaptabilitas, semakin baik fungsi keluarga tersebut.

Berdasarkan keberfungsian ke-luarga, kategori balanced families adalah keluarga dengan tipe relasi flexible separated, flexible connected, structured separated, dan structured connected. Midrange families memiliki skor ekstrim pada salah satu dimensinya, baik kohesi maupun adaptabilitas, dan skor seimbang pada dimensi lainnya. Tipe relasi orang tuaremaja pada kategori ini adalah chaotically separated, chaotically connected, structurally disengaged, structurally enmeshed, flexibly disengaged, flexbly enmeshed, rigidly separated, dan rigidly connected. Extreme families atau unbalanced families adalah keluarga yang memiliki skor ekstrim di kedua dimensinya. Tipe-tipe extreme families biasanya lebih sulit untuk berfungsi layaknya sebagai sebuah keluarga. Tipe relasi pada kategori ini adalah chaotically disengaged, chaotically enmeshed, rigidly disengaged, dan rigidly enmeshed.

Berdasarkan penjelasan tersebut, peneliti tergelitik untuk mendalami apakah ada pengaruh dari keseimbangan relasi atau fungsionalitas relasi orang tuaremaja dengan orientasi masa depan. 


\section{Metode Penelitian}

Keberhasilan suatu penelitian akan tergantung dari metode penelitian yang digunakan oleh peneliti. Untuk menguji hipotesis dan menjelaskan hubungan sebabakibat dari variabel penelitian ini, penulis menggunakan metode kuantitatif. Menurut Sugiyono (2011) metode penelitian kuantitatif adalah penelitian dengan memperoleh data yang berbentuk angka atau data kualitatif yang diangkakan. Dalam penelitian ini, objek penelitian adalah keseimbangan relasi orang tuaremaja dan Orientasi Masa Depan (OMD). Di mana variabel independen $(\mathrm{X})$ adalah keseimbangan relasi orang tua-remaja dan variabel dependen (Y) adalah Orientasi Masa Depan (OMD). Subjek penelitian ini adalah remaja kelas XII SMA di Kota Bandung.

\section{Populasi dan Sampel}

Populasi dalam penelitian ini adalah siswa SMA kelas XII di wilayah kota Bandung yang peneliti asumsikan sebagai remaja. Pengambilan sampel yang digunakan dalam penelitian ini yaitu metode probability sampling yaitu semua anggota atau subjek penelitian memiliki peluang yang sama untuk dipilih sebagai sampel.

Pemilihan sampel menggunakan cluster sampling yaitu model pemilihan sampel yang dilakukan dengan cara pengelompokkan berdasarkan wilayah geografis kota Bandung yang terdiri dari Bandung Timur, Bandung Utara, Bandung Tenggara, Bandung Barat, dan Bandung Selatan. Cluster sampling digunakan dalam dua tahap (two stage cluster sampling), pertama tahap memilih sekolah, dan tahap kedua memilih kelas.

Pemilihan sampel pada penelitian ini diawali dengan pengumpulan data populasi SMA Negeri dan Swasta seluruh wilayah di kota Bandung di mana terdapat 5 Wilayah kota Bandung, selanjutnya diambil 1 sekolah negeri dan satu sekolah swasta pada masing-masing wilayah kota Bandung. Selanjutnya dari tiap sekolah yang telah dipilih secara acak masingmasing 1 kelas XII terpilih yang nantinya wilayah tersebut akan menjadi target untuk pengambilan sampel penelitian. Dari hasil two stage cluster sampling, didapat sampel sebanyak 358 siswa di Kota Bandung.

Pengukuran pola relasi meng-gunakan kuesioner yang dirancang oleh Olson (2000) tentang Family System dan dikembangkan oleh peneliti sesuai dengan kebutuhan penelitian. Sedangkan untuk orientasi masa depan menggunakan menggunakan alat ukur yang diadaptasi dari Sangadji (2010).

\section{Uji Coba Kuesioner}

Validitas merupakan ukuran yang benar-benar mengukur apa yang akan diukur. Jadi dapat dikatakan semakin tinggi validitas suatu alat test, maka alat tersebut makin mengenai sasarannya, atau semakin menunjukan apa yang seharusnya diukur. Jadi validitas menunjukan kepada ketepatan dan kecermatan test dalam menjalankan fungsi pengukurannya.

Untuk menentukan kevaliditasan dari item kuesioner digunakan metode korelasi product moment. Jika nilai koefisien korelasinya yang lebih besar dari 0,3 maka item-item tersebut dinyatakan valid (Kaplan., \& Saccuzo, 1993).

Dari hasil uji validitas terhadap 30 responden menunjukkan alat ukur keseimangan pola relasi orang tua-remaja sebanyak 29 item dan alat ukur variabel Orientasi Masa Depan sebanyak 41 item.

\section{Reliabilitas Instrumen}

Reliabilitas artinya tingkat kepercayaan hasil suatu pengukuran. Pengukuran yang memiliki tingkat reliabilitas tinggi yaitu pengukuran yang mampu memberikan hasil yang terpercaya (reliabel). Untuk menguji reliabilitas dalam penelitian ini, penulis menggunakan koefisien reliabilitas Alpha Cronbach

Berdasarkan hasil perhitungan data awal, pada tabel 2 dapat dilihat bahwa 
Tabel 1. Hasil Uji Validitas Item

\begin{tabular}{lccc}
\hline & $\begin{array}{c}\text { Jumlah } \\
\text { Item }\end{array}$ & $\begin{array}{c}\text { Jumlah Item } \\
\text { Tidak Valid }\end{array}$ & $\begin{array}{c}\text { Jumlah } \\
\text { Item Valid }\end{array}$ \\
\hline Keseimbangan Relasi : & & & \\
$1 \quad$ Kohesi & 27 & 12 & 15 \\
$2 \quad$ Adaptabilitas & 23 & 9 & 14 \\
\hline Jumlah & 50 & 21 & 29 \\
\hline Orientasi Masa Depan & & & 14 \\
$1 \quad$ Motivasi & 16 & 2 & 16 \\
2 Perencanaan & 19 & 3 & 11 \\
$3 \quad$ Evaluasi & 20 & 9 & 41 \\
\hline Jumlah & 55 & 14 & \\
\hline
\end{tabular}

Tabel 2. Hasil Uji Reliabilitas

\begin{tabular}{lcc}
\hline \multicolumn{1}{c}{ Variabel } & Alpha Cronbach & Kriteria Reliabilitas \\
\hline Pola Relasi Orang Tua-Remaja & 0,864 & Tinggi \\
Orientasi Masa Depan Bidang & 0,929 & Tinggi Sekali \\
Pendidikan & & \\
\hline
\end{tabular}

keseimbangan relasi memiliki koefisien Alpha Cronbach sebesar 0,864 dan variabel orientasi masa depan sebesar 0,929. Kedua nilai tersebut telah lebih dari 0,70 sehingga dapat dikatakan bahwa kuesioner untuk mengukur keseimbangan relasi dan OMD telah reliabel.

\section{Analisis Data}

Teknik analisis yang digunakan adalah analisis korelasi dan regresi logistik. Regresi logistik adalah prosedur pemodelan yang diterapkan untuk memodelkan variabel respon (Y) yang bersifat kategori berdasarkan satu atau lebih variabel prediktor (X), baik itu yang bersifat kategori maupun kontinu (Kuncoro \& Mudrajad, 2006). Variabel respon (Y) dalam penelitian ini mengkategorikan OMD pendidikan remaja menjadi dua kategori, yaitu jelas dan tidak jelas. Untuk variabel prediktornya, yaitu keseimbangan pola relasi menggunakan tiga kategori, yaitu balanced, mid range dan unbalanced.

Secara umum model probabilitas regresi logistik dengan melibatkan beberapa variable prediktor (X) dapat diformulasikan sebagai berikut :

$$
E(y \mid x)=\frac{e^{\left(\beta_{0}+\beta_{1} x_{1}+\beta_{2} x_{2}+\ldots+\beta_{p} x_{p}\right)}}{1+e^{\left(\beta_{0}+\beta_{1} x_{1}+\beta_{2} x_{2}+\ldots+\beta_{p} x_{p}\right)}}
$$

\section{Uji model secara parsial}

Dengan hipotesis sebagai berikut :

$\mathrm{H}_{0}: \beta_{j}=0$

$\mathrm{H}_{1}: \beta_{j} \neq 0$

Statistik uji :

$W_{j}=\left(\frac{\beta_{j}}{S e_{\left(\beta_{j}\right)}}\right)^{2}$

Statistik W mengikuti distribusi Chi Kuadrat dengan derajat bebas 1 . Jika $\mathrm{W}>$, maka tolak hipotesis nol. Berarti variabel bebas signifikan menjelaskan variabel terikat pada taraf $\mu$. Kriteria uji yang dapat digunakan yaitu Tolak $\mathrm{H}_{0}$ jika nilai signifikan $\mathrm{W}_{\mathrm{j}} \leq \alpha$, terima dalam hal lainnya. 


\section{Hasil Penelitian dan Pembahasan}

Pada tabel 3 dapat dilihat bahwa sebanyak 358 kuesioner disebarkan kepada responden dengan jenis kelamin laki-laki sebanyak 175 orang dan 183 orang perempuan. Usia responden berkisar antara 15 hingga 19 tahun. Sebanyak 71,23\% dengan usia 17 tahun, dan sebagian kecil lainnya dengan usia 18 tahun $(18,44 \%), 15$ tahun dan 16 tahun.

Sebanyak 301 remaja tinggal dengan orang tuanya, hanya sebagian kecil yang tinggal dengan ibu saja (sebanyak 15 orang), walinya (sebanyak 25 orang), kost (10 orang), dan sebagian kecil lainnya tinggal dengan ayah saja, kakak, dan nenek. Sebanyak 123 remaja tinggal dengan ayah yang berpendidikan S1, sebanyak 106 lainnya dengan pendidikan ayah adalah SMA, hanya sebangian kecil dengan pendidikan ayah SMP dan SD. Sementara jika dilihat dari pendidikan ibu, sebagian besar ibu berpendidikan SMA (sebanyak 125 orang), sebagian lainnya dengan ibu berpendidikan S1 (sebanyak 114 orang remaja). Hanya sebagian kecil saja dengan ibu yang berpendidikan SMP dan SD.

Tabel 3. Karakteristik Responden

\begin{tabular}{lcc}
\hline \multicolumn{1}{c}{ Karakteristik } & f & \% \\
\hline Jenis Kelamin & & \\
Laki-laki & 175 & 48,88 \\
Perempuan & 183 & 51,12 \\
& & \\
Usia & & \\
15 tahun & 2 & 0,56 \\
16 tahun & 35 & 9,78 \\
17 tahun & 255 & 71,23 \\
18 tahun & 66 & 18,44 \\
& & \\
Tinggal Dengan & & \\
Ayah & 7 & 1,96 \\
Ibu & 15 & 4,19 \\
Kost & 10 & 2,79 \\
Orang Tua & 301 & 84,08 \\
Wali & 25 & 6,98 \\
Pendidikan Ayah & & \\
\hline
\end{tabular}

\begin{tabular}{lcc}
\hline SD & 8 & 2,23 \\
SMP & 15 & 4,19 \\
SMA & 106 & 29,61 \\
D3 & 5 & 1,40 \\
S1 & 123 & 34,36 \\
S2 & 73 & 20,39 \\
S3 & 28 & 7,82 \\
& & \\
Pendidikan Ibu & & \\
SD & 19 & 5,31 \\
SMP & 14 & 3,91 \\
SMA & 125 & 34,92 \\
D3 & 1 & 0,28 \\
S1 & 9 & 2,51 \\
S2 & 114 & 31,84 \\
S3 & 38 & 10,61 \\
\hline
\end{tabular}

Berdasarkan hasil perhitungan kombinasi antara dimensi kohesi dan adaptabilitas, terdapat $86,03 \%$ remaja dengan pola relasi orang tua yang seimbang (balanced), sebanyak $10,06 \%$ lainnya dengan kategori midrange dan sisanya sebanyak 3,91\% dengan kategori yang tidak seimbang (unbalanced).

Tabel 4. Keseimbangan Pola Relasi Orang Tua - Remaja

\begin{tabular}{clcc}
\hline No & $\begin{array}{c}\text { Keseimbangan } \\
\text { Pola Relasi } \\
\text { Orang Tua- } \\
\text { Remaja }\end{array}$ & F & $\%$ \\
\hline 1 & Balance & 308 & 86,03 \\
2 & Mid range & 36 & 10,06 \\
3 & Unbalance & 14 & 3,91 \\
& Total & 358 & 100,00 \\
\hline
\end{tabular}

Dukungan keluarga menurut Francis dan Sariadarma (dalam Ambari, 2010) adalah bantuan yang diterima salah satu anggota keluarga dari anggota keluarga lainnya dalam rangka men-jalankan fungsifungsi yang terdapat di dalam sebuah keluarga. Santrock (2003) berpendapat bahwa keluarga merupakan pilar utama dan pertama dalam mem-bentuk anak untuk mandiri. Dukungan yang paling besar di dalam lingkungan rumah adalah bersumber 


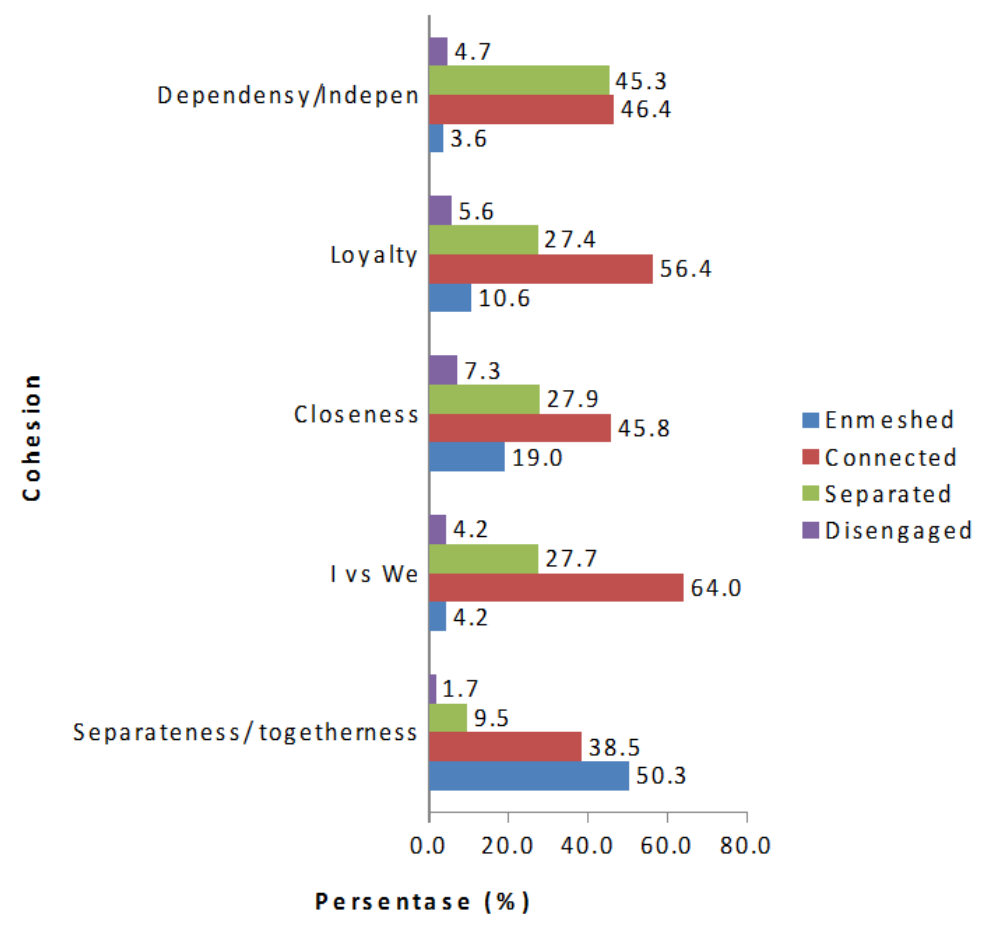

Gambar 2. Gambaran Kelima Karakteristik Kohesi

dari orang tua. Dukungan orang tua sangat penting bagi individu dalam menjalani kehidupannya. Fischer (1998) juga menyatakan bahwa salah satu hal yang berperan penting di dalam pembentukan kemandirian belajar pada diri siswa adalah dari dukungan yang diterima oleh siswa dari komunitas tempat siswa berada, seperti dari sekolah, teman, orang tua, guru, dan sebagainya.

Ambari (2010) menyatakan dukung-an orang tua, dapat menciptakan kekuatan keluarga, memperbesar peng-hargaan terhadap diri sendiri, mempunyai strategi pencegahan yang utama bagi seluruh keluarga dalam menghadapi tantangan kehidupan sehari-hari. Saranson (dalam Martha, 1991) mengatakan bahwa fungsi dukungan orang tua adalah dengan memberikan penguatan moral bagi remaja. Begitu juga menurut Sarafino (2006) yang menyatakan bahwa dukungan sosial orang tua mengacu pada memberikan kenyamanan pada orang lain, merawatnya atau menghargainya.

Adanya interaksi yang seimbang antara orang tua dan remaja menunjukkan adanya komunikasi yang positif. Dengan adanya dukungan orang tua atas keputusan dan rencana yang disusun oleh remaja dapat tercermin dari berbagai perlakuan yang diberikan orang tua kepada remaja tersebut. Misalnya saja, memberikan masukanmasukan mengenai pilihan mana yang terbaik, serta mengawasi segala usaha yang anak lakukan untuk meraih pendidikan mendatang. Untuk menunjukan penghargaan kepada anak, orang tua memberikan kepercayaan kepada anak untuk memilih bidang studi yang disukainya setelah lulus SMA/SMK yang dalam jangka lebih panjangnya akan berdampak pada pemilhan pendidikan di Perguruan Tinggi mendatang.

Terdapat dua dimensi pembentuk keseimbangan relasi orang tua-remaja, yaitu dimensi kohesi dan adaptabilitas. Kelima karakteristik dimensi kohesi terlihat pada Gambar 2.

Dimensi kohesi merupakan penghayatan siswa kelas XII terhadap ke- 
dekatan yang terjalin dengan orang tua. Kohesi memiliki 5 karakteristik.

Separateness/ togetherness, yaitu frekuensi penghayatan siswa kelas XII terhadap intensitas kebersamaan yang terjalin dengan orang tua, di mana separateness menunjukkan frekuensi yang sangat jarang menjalin keber-samaan dengan orang tua, sedangkan togetherness menunjukkan frekuensi yang sangat sering menjalin ke-bersamaan dengan orang tua. Dari grafik di atas, dapat dilihat bahwa, lebih dari setengah responden tergolong memiliki separateness dengan derajat enmeshed atau very high togetherness. Hubungan enmeshed akan memunculkan masalah baik bagi perkembangan individu sendiri maupun bagi perkembangan hubungan diantara mereka. Salah satu cara untuk memperbaiki hubungan yang enmeshed ialah setiap orang harus berusaha meluangkan waktu untuk berpisah dari pasangan atau orang tua guna mengembangkan minat-minat dan kemampuan-kemampuan individual. Namun, ini tidak berarti pergi ke esktrim lain, yaitu hubungan yang disengaged.

I vs We, yaitu frekuensi penghayatan siswa kelas XII terhadap kemam-puannya dalam menghayati tanggung jawab dimana pada $I$ berarti siswa kelas XII menghayati tanggung jawab lebih pada dirinya sedangkan We berarti siswa kelas XII lebih meng-hayati tanggung jawab pada orang tua. Dilihat dari I vs We, lebih dari setengah responden $(64 \%)$ dengan derajat connected (More emphasis on "We" than "I").

Closeness, yaitu frekuensi penghayatan siswa kelas XII terhadap kedekatan emosional yang terjalin berupa keterbukaan dan perhatian antara kedua belah pihak sehingga dapat saling memahami. Sama halnya dengan $I$ vs We, hampir setengah res-ponden dengan closeness pada derajat connected, yaitu sebanyak $45,8 \%$.

Loyalty, yaitu frekuensi penghayatan siswa kelas XII terhadap perasaan bangga, mempercayai, menghormati dan membela orang tua. Lebih dari setengah responden dengan closeness pada derajat connected, yaitu sebanyak 56,4\%. Artinya, tingkat kedekatan antara remaja dengan orang tua dikategorikan cukup hingga hubungan kedekatan yang kuat.

Independencel dependence, yaitu frekuensi penghayatan ketergantungan siswa kelas XII terhadap orang tua, dimana independence menunjukkan frekuensi penghayatan yang tidak tergantung terhadap orang tua, sedangkan dependence menunjukkan frekuensi penghayatan yang ber-gantung terhadap orang tua. Untuk karakteristik dependency kurang dari setengah dengan derajat connected $(46,4 \%)$ dan separated $(45,3 \%)$. Jika berada pada derajat connected memiliki arti individu lebih rendah pada independensi dibandingkan dependennya. Jika pada derajat separated memiliki arti individu lebih tinggi pada independensi dibandingkan dependennya.

Gambaran keempat karakteristik dimensi adaptability digambarkan pada Gambar 3. Dimensi Adaptabilitas merupakan penghayatan siswa kelas XII terhadap kemampuan orang tua dan remaja untuk mengubah struktur kekuasaan, peran dan aturan-aturan di dalam berhubungan terhadap berbagai situasi. Adaptabilitas memiliki 4 karakteristik. 


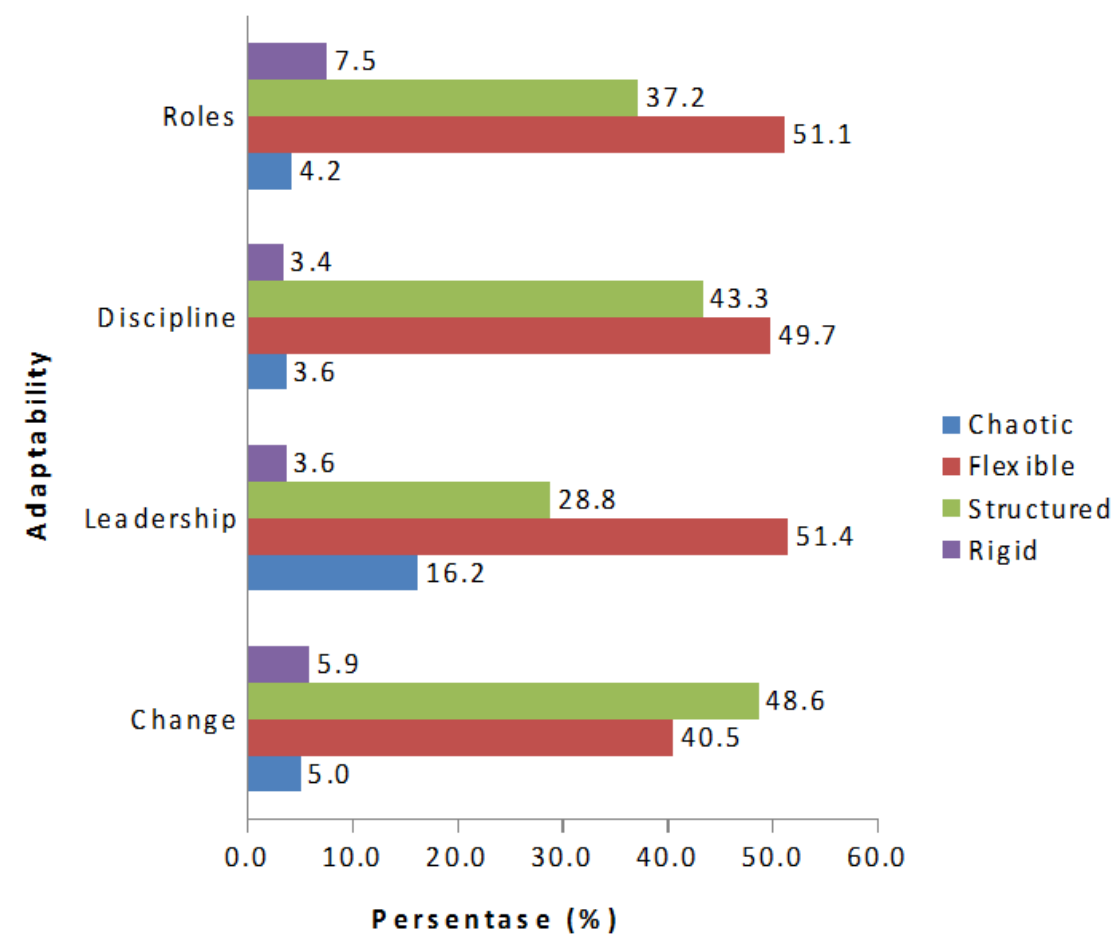

Gambar 3. Gambaran Keempat Karakteristik Adaptability

Change, yaitu frekuensi penghayatan siswa kelas XII terhadap perubahanperubahan yang menyangkut rutinitas keluarga yaitu perubahan yang disebabkan oleh siklus kehidupan seperti perubahan perlakuan orang tua terhadap siswa kelas XII yang sedang tumbuh dewasa. Dari grafik di atas, dapat dilihat bahwa untuk karakteristik change, sebanyak 48,6\% berada pada derajat structured, dan 40,5\% pada derajat flexible.

Leadership, yaitu frekuensi penghayatan siswa kelas XII tentang sistem kekuasaan, dominasi pengambilan keputusan yang dilakukan oleh orang tua dan keterlibatan siswa kelas XII dalam menyampaikan pendapat mengenai keadaan orang tua maupun keputusan yang diambil oleh orang tua. Lebih dari setengah responden $(51,4 \%)$ memiliki leadership pada derajat flexible.

Discipline, yaitu frekuensi penghayatan siswa kelas XII mengenai konsistensi pelaksanaan peraturan, reward dan hukuman yang dilakukan oleh orang tua terhadap siswa kelas XII. Hampir setengah responden $(49,7 \%)$ memiliki leadership pada derajat flexible.

Roles, yaitu frekuensi penghayatan siswa kelas XII tentang perubahan peran orang tua dan remaja dalam menjalankan tanggung jawabnya. Lebih dari setengah responden $(51,1 \%)$ memiliki leadership pada derajat flexible.

Tabel 5. Orientasi Masa Depan Pendidikan Remaja Kota Bandung

\begin{tabular}{clcc}
\hline No & $\begin{array}{c}\text { Orientasi Masa Depan } \\
\text { Pendidikan (OMD) }\end{array}$ & f & \% \\
\hline 1 & Jelas & 225 & 62,85 \\
2 & Tidak Jelas & 133 & 37,15 \\
& Total & 358 & 100,00 \\
\hline
\end{tabular}

Dari hasil penelitian ini diketahui bahwa siswa SMA kelas XII di kota Bandung memiliki kejelasan orientasi masa depan bidang pendidikan sebanyak 225 responden atau sebesar $62,85 \%$. Sementara itu responden yang mem- 


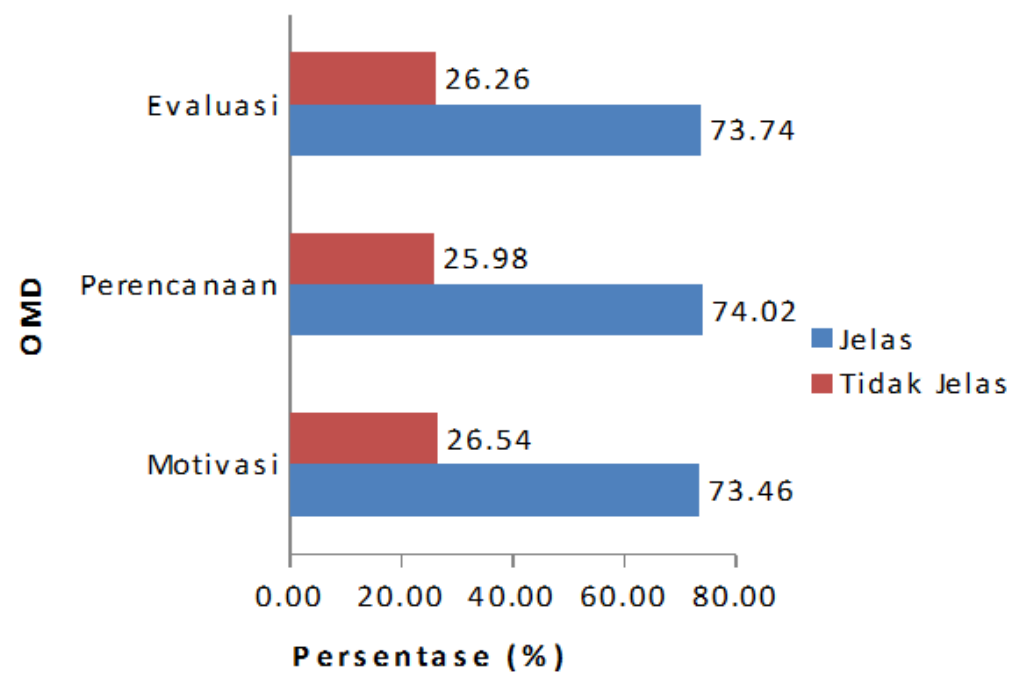

\section{Gambar 4. Dimensi Orientasi Masa Depan Remaja}

perlihatkan ketidakjelasan orientasi masa depan bidang pendidikan sebanyak 133 responden atau sebesar $37,15 \%$. Kondisi ini cukup wajar mengingat pada usia ini remaja sudah lepas dari ketergantungan pada orang tua dan pengaruh orang tua secara berangsur mulai berkurang (Santrock, 2010). Remaja telah menyatu pada kelompok teman sebayanya untuk mencapai perkembangan kemandiriannya. Pada masa ini remaja lebih banyak berinteraksi dengan orang lain di luar orang tua seperti teman sebaya, guru ataupun kakak tingkatnya. Berkaitan dengan hal ini, dari data pendukung ditemukan bahwa responden yang me-miliki kejelasan orientasi masa depan bidang pendidikan juga sering men-diskusikan permasalahan terkait pen-didikan di perguruan tinggi dengan teman, kakak, dan juga guru sehingga hal ini dapat dimungkinkan sebagai faktor lain yang berhubungan dengan orientasi masa depan bidang pendidikan.

Temuan lain dalam penelitian ini menunjukkan bahwa beberapa remaja $(37,15 \%)$ memiliki orientasi masa depan dalam bidang pendidikan yang tidak jelas. Orientasi masa depan bidang pendidikan yang tidak jelas menunjukkan relasi dengan orang tua seperti jarangnya orang tua bertanya atau berdiskusi dengan remaja berkaitan dengan persiapan menuju perguruan tinggi, penetapan jurusan di perguruan tinggi, perencanaan pendidikan di perguruan tinggi.

Remaja menjadi kebingungan karena tidak adanya bantuan orang terdekat yaitu orang tua dalam mem-berikan penjelasan dan penguatan terkait pendidikan yang akan ditempuh di masa depan. Sebagai contoh, remaja yang diberi kebebasan di mana orang tua tidak mengarahkan jurusan di perguruan tinggi membuat remaja mengalami kebingunan dan sulit untuk menetapkan tujuannya dalam pendidikan lanjutan. Ini berarti peran orang tua dalam memberi dukungan dan penguatan dalam pengambilan keputusan khususnya dalam bidang pendidikan (kelanjutan di perguruan tinggi) sangat penting sebagaimana pendapat Santrock (2010) yang menjelaskan bahwa remaja tetap membutuhkan orang tua untuk membimbing.

Tiga proses pada orientasi masa depan yaitu motivasi, perencanaan dan evaluasi pada gambar 4 menunjukkan responden yang memiliki motivasi yang jelas yaitu sebanyak $73,46 \%$ mem-perlihatkan adanya penetapan pilihan pendidikan serta berusaha mencari informasi yang berkaitan 
dengan pen-didikan lanjutan yang diminati. Namun pada responden yang tidak memiliki kejelasan motivasi memperlihatkan masalah dalam menetapkan minat dan tujuan pendidikan lanjutan di perguruan tinggi.

Nurmi juga menekankan pen-tingnya memiliki pengetahuan untuk kejelasan orientasi masa depan. Dengan memiliki pengetahuan, individu dapat membuat tujuan yang lebih spesifik (Nurmi, 1991). Dari hasil kuesioner pada responden yang belum memperlihatkan kejelasan motivasi, diketahui bahwa responden tersebut belum berusaha untuk bertanya atau mencari informasi pada orang lain, belum memfokuskan diri pada mata pelajaran tertentu, dan tidak tertarik untuk mencari tahu program studi lanjutan yang akan ditekuni. Padahal informasi-informasi tersebut diperlukan remaja untuk membantu mereka dalam memilih dan menetapkan bidang pendidikan yang sesuai serta dapat juga dipakai dalam menyusun sejumlah rencana dan strategi yang jelas dan terarah menuju bidang pendidikan yang diinginkan.

Hasil pengukuran terhadap perencanaan di antaranya 74,02\% yang sudah memiliki perencanaan yang jelas. Jumlah tersebut lebih besar dibandingkan dengan proses yang lain dalam orientasi masa depan bidang pendidikan. Artinya responden memiliki kemampuan untuk menyusun rencana dan strategi yang berguna untuk merealisasikan pendidikan di masa depan. Dalam proses perencanaan diperlukan pengetahuan yang berguna bagi responden dalam menyusun rencana dan strategi pendidikannya di masa depan. Hal tersebut seperti yang diungkapkan Nurmi (1991) bahwa memiliki informasi dan pengetahuan merupakan sesuatu yang penting bagi seseorang untuk menyusun sejumlah rencananya di masa depan.

Responden yang menunjukkan kejelasan perencanaan memiliki pengetahuan mengenai persyaratan dan kemampuan yang harus dipenuhi untuk mewujudkan masa depan bidang pendidikan, kemudian responden akan menemukan cara yang paling efektif untuk mencapai tujuan tentang pendidikan lanjutan yang telah dipilih. Hal ini akan berpengaruh terhadap kemungkinan realisasi perencanaan, di mana responden yang memiliki kejelasan perencanaan akan menjalankan rencana serta strategi yang telah disusun. Dengan begitu, responden yang memiliki perencanaan yang jelas memiliki tujuan yang lebih realistis sehingga peluang mereka untuk berhasil mencapai bidang pendidikan yang ditetapkan pun semakin besar.

Dari hasil kuesioner yang telah dikumpulkan diketahui bahwa responden dengan kejelasan perencanaan mampu menyusun sejumlah rencana berupa mempertimbangkan nilai-nilai akademik dan menambah atau memperbaiki waktu belajar.

Hal yang berbeda justru ditunjukkan oleh responden yang memiliki ketidakjelasan perencanaan. Mereka tidak memiliki informasi dan pengetahuan sehingga berdampak pada penyusunan rencana yang tidak terarah dan dikhawatirkan pendidikan yang diharapkan pun tidak dapat terwujud dengan baik.

Hasil perhitungan terhadap proses evaluasi diketahui bahwa $73,74 \%$ responden memiliki evaluasi yang jelas dan hanya sedikit responden yang memiliki evaluasi yang tidak jelas. Responden diasumsikan tidak akan mengalami kesulitan dalam menilai kemungkinan terwujudnya pendidikan di masa depan apabila mengetahui bidang pendidikan apa yang akan dipilih ataupun ditekuni. Selain itu, responden cenderung mudah membayangkan bentuk realisasi tercapainya pendidikan yang ia inginkan sehingga dapat menimbulkan perasaan optimis yang tercermin dari hasil kuesioner mereka. Pengetahuan yang memadai tentang pendidikan di masa depan dan kemampuan responden dalam menyusun rencana dan strategi akan memudahkan 


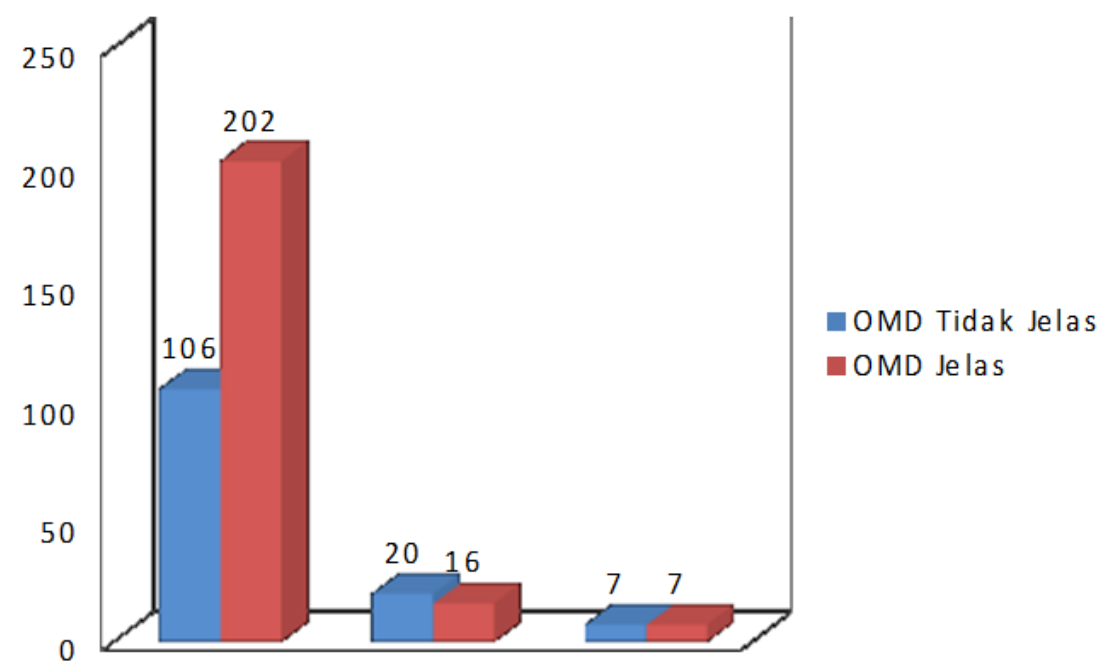

Gambar 5. Keseimbangan Pola Relasi Orang Tua-Remaja dan Orientasi Masa Depan Bidang Pendidikan Remaja Kota Bandung

responden ketika mengevaluasi keberhasilannya di masa depan.

Dari hasil kuesioner diperoleh informasi bahwa remaja yang memiliki evaluasi tidak jelas lebih mengganggap bahwa faktor keberuntungan memberikan kontribusi yang besar dalam menentukan masa depan bidang pendidikan mereka. Dampaknya, usaha-usaha yang dikerahkanpun tidak maksimal karena mereka sendiri tidak yakin akan kemampuan diri dan keterwujudan pendidikan yang mereka inginkan.

Dari item-item kuesioner penelitian yang ada dalam proses evaluasi, diketahui bahwa responden yang belum memiliki evaluasi yang jelas pada pendidikan lanjutan menunjukkan belum adanya bayangan yang jelas tentag pendidikan yang akan dijalaninya nanti. Hal berbeda ditunjukkan oleh responden-responden yang memiliki evaluasi yang jelas di mana mereka sudah dapat membayangkan kemungkinan akan tercapainya pendidikan lanjutan yang mereka inginkan sehingga perasaan yang muncul ketika mengevaluasi pendidikannya di masa depan pun adalah perasaan senang dan optimis (yakin). Mereka juga telah mengetahui persyaratan- persyaratan yang harus mereka penuhi agar dapat berhasil dalam bidang pendidikan yang ingin dituju. Dengan begitu, mereka dapat menentukan apakah tujuan yang ingin dicapai perlu diubah atau tidak dan perencanaan yang telah disusun apakah perlu dimodifikasi atau tidak.

Dari hasil perhitungan terhadap prosesproses dari orientasi masa depan bidang pendidikan di atas (motivasi, perencanaan, dan evaluasi) maka dapat digambarkan bagaimana orientasi masa depan bidang pendidikan dari responden yaitu siswa SMA kelas XII di kota Bandung.

Ketiga proses tersebut saling berkaitan dalam membentuk kejelasan atau ketidakjelasan orientasi masa depan bidang pendidikan dan dapat dikatakan sebagian besar siswa sudah memiliki gambaran orientasi masa depan bidang pendidikan yang jelas. Apabila dikaitkan dengan proses-proses di dalam orientasi masa depan, responden yang telah menentukan tujuan masa depannya yang jelas diharapkan juga termotivasi untuk membuat dan menjalankan rencana pendidikan mereka. Apabila tujuan siswa sudah jelas maka perencanaan yang mereka susun pun dapat lebih terarah. 
Tabel 6. Hasil Uji Wald Analisis Regresi Logistik Keseimbangan Pola Relasi Orang Tua-Remaja terhadap OMD Pendidikan Remaja Kota Bandung

\begin{tabular}{|c|c|c|c|c|c|c|}
\hline & $B$ & S.E. & Wald & $D f$ & Sig. & $\operatorname{Exp}(B)$ \\
\hline Tipe.Relasi & & & 24,690 & 2 & 0,000 & \\
\hline $\begin{array}{l}\text { Tipe.Relasi } \\
\text { (Unbalance) }\end{array}$ & $-2,784$ & 1,021 & $-7,435$ & 1 & 0,006 & 0,062 \\
\hline $\begin{array}{l}\text { Tipe.Relasi (Mid } \\
\text { Range) }\end{array}$ & $-0,736$ & 0,600 & $-17,840$ & 1 & 0,000 & 0,479 \\
\hline Constant & 0,854 & 0,127 & 45,491 & 1 & 0,000 & 2,348 \\
\hline
\end{tabular}

Keterangan : sebagai reference adalah kategori keseimbangan relasi balance

Sumber : Pengolahan Data 2016

Dari hasil penelitian didapat bahwa lebih dari setengah remaja dengan relasi dengan orang tua yang seimbang (balance) memiliki kejelasan orientasi masa depan, yaitu sebanyak 202 remaja $(56,42 \%)$. Dari 36 remaja dengan keseimbangan tipe relasi dengan kategori mid range, hampir setengah dari mereka (sebanyak 16 remaja) memiliki ketidakjelasan orientasi masa depan. Sedangkan remaja yang memiliki ketidakseimbangan relasi dengan orang tua memiliki ketidakjelasan orientasi masa depan.

Untuk melihat pengaruh keseimbangan pola relasi orang tua dan remaja terhadap orientasi masa depan pendidikannya digunakan analisis regresi logistik:

Berdasarkan hasil pengujian. secara keseluruhan, keseimbangan pola relasi memiliki pengaruh yang signifikan pada orientasi masa depan pendidikan remaja di Bandung $(\mathrm{p}<0,001)$. Untuk keseimbangan relasi yang pertama, yaitu unbalance memiliki pengaruh yang signifikan pada orientasi masa depan pendidikan remaja di Bandung $(\mathrm{p}<0,001)$ dan memiliki odds ratio sebesar 0,062 yang menunjukkan keseimbangan pola relasi orang tua-remaja yang unbalance memiliki kemungkinan sebesar 0,062 kali untuk memiliki OMD pendidikan yang jelas dibandingkan dengan keseimbangan pola relasi orang tua-remaja yang balance. Dengan kata lain, keseimbangan pola relasi orang tua-remaja yang balance memiliki kemungkinan sebesar 16,181 (1/0,068) kali untuk kejelasan OMD pendidikan dibandingkan dengan keseimbangan pola relasi orang tuaremaja yang unbalance.

Hasil yang tidak jauh berbeda juga ditunjukkan oleh keseimbangan pola relasi orang tua-remaja dengan kategori mid range. Untuk keseimbangan relasi yang kedua, yaitu mid range memiliki pengaruh yang signifikan pada orientasi masa depan pendidikan remaja di Bandung $(\mathrm{p}<0,001)$ dan memiliki odds ratio sebesar 0,479 yang menunjukkan keseimbangan pola relasi orang tua-remaja dengan kategori mid range memiliki kemungkinan sebesar 0,479 kali untuk memiliki OMD pendidikan yang jelas dibandingkan dengan keseimbangan pola relasi orang tua-remaja yang balance. Dengan kata lain, keseimbangan pola relasi orang tua-remaja yang balance memiliki kemungkinan sebesar 2,088 $(1 / 0,479)$ kali untuk memiliki OMD pendidikan yang jelas dibandingkan dengan keseimbangan pola relasi orang tua-remaja dengan kategori mid range.

Dari kedua nilai odds ratio dapat dilihat bahwa semakin seimbang relasi orang tua - remaja maka akan semakin mungkin pula mereka memiliki orientasi masa depan pendidikan yang jelas. Semakin seimbang/ balance pola relasi yang ditunjukkan pada dimensi adaptabilitas dan kohesi maka semakin jelas pula orientasi masa depan di bidang pendidikan. Interaksi yang dilakukan remaja dengan orang tua ternyata terbukti memiliki hubungan terhadap kejelasan orientasi masa depan di bidang pendidikan sebab senada dengan pernyataan Olson (1991) bahwa relasi dalam keluarga mempengaruhi sikap 
Tabel 7. Hasil Analisis Korelasi Dimensi Keseimbangan Pola Relasi Orang Tua-Remaja dengan Orientasi Masa Depan Pendidikan Remaja Kota Bandung

\begin{tabular}{clcccc}
\hline No & $\begin{array}{c}\text { Dimensi Keseimbangan Pola } \\
\text { Relasi Orang Tua- Remaja }\end{array}$ & $\begin{array}{c}\text { Koefisien } \\
\text { Korelasi }\end{array}$ & $\begin{array}{c}\text { p- } \\
\text { value }\end{array}$ & Keterangan & $\begin{array}{c}\text { Koefisien } \\
\text { Determinasi }\end{array}$ \\
\hline 1 & Kohesi & 0,550 & 0,000 & Signifikan & $30,25 \%$ \\
2 & Adaptabilitas & 0,413 & 0,000 & Signifikan & $17,06 \%$ \\
\hline
\end{tabular}

Sumber : Pengolahan Data 2016

seseorang. Artinya pada saat remaja berelasi dengan orang tuanya, penerimaan dan penghayatan terhadap orang tua baik dalam hal kedekatan dan adaptasi memiliki hubungan dengan orientasi masa depan remaja dalam bidang pendidikan.

Sebagaimana hasil penelitian lain yang menunjukkan adanya hubungan kualitas relasi orang tua-remaja dengan orientasi masa depan bidang pendidikan (Sangadji, 2010), penelitian ini juga menunjukkan dimana tipe pola relasi flexible separated, dan flexible connected yang tergolong tipe relasi balance berhubungan dengan kejelasan orientasi masa depan bidang pendidikan. Artinya semakin seimbang/ balance pola relasi orang tua-remaja yang ditunjukkan melalui dimensi kohesi dan adaptabilitas, maka semakin jelas orientasi masa depan remaja tersebut pada bidang pendidikan. Hal ini sejalan dengan penelitian Rodick (dalam Olson, 1989) yang menemukan bahwa keluarga balanced atau seimbang, memiliki keahlian berkomunikasi yang lebih positif yang berarti bahwa orang tua dalam berelasi yang memiliki keseimbangan antara kohesi dan adaptabilitas mampu mengajak responden untuk berdiskusi berkaitan dengan orientasi masa depan bidang pendidikan, serta responden akan lebih terbuka menyampaikan permasalahannya.

Hasil analisis korelasi menunjukkan bahwa dimensi kohesi memiliki hubungan yang signifikan pada OMD pendidikan remaja $(\mathrm{p}<0,001)$ dengan besar korelasi 0,550. Hal yang sama ditunjukkan pula oleh dimensi adaptabilitas $(\mathrm{p}<0,001)$ dengan besar korelasi sebesar 0,413.
Dimensi kohesi memiliki hubungan yang lebih besar dibandingkan derajat adaptabilias. Dimensi kohesi pada pola relasi ini menunjukkan bahwa kemampuan menyeimbangkan antara area separateness dan togetherness mereka. Santrock (2010) berpendapat bahwa orang tua yang bijaksana akan melepaskan kendali di bidangbidang di mana remaja dapat mengambil keputusan-keputusan yang masuk akal dan terus membimbing remaja untuk mengambil keputusan-keputusan yang tepat pada bidang-bidang di mana pengetahuan remaja terbatas. Hal ini berarti orang tua akan memberi kebebasan pada remaja untuk menetapkan pilihan pendidikan/ jurusan yang sesuai dengan minat dan tujuan pendidikan lanjutan pada remaja.

Responden yang memiliki relasi kehangatan dengan keluarga juga memperlihatkan adanya kejelasan dalam menentukan pilihan masa depannya. Hasil kuesioner menunjukkan kedekatan orang tua dengan responden, misalnya ketika makan bersama, orang tua memberikan informasi tentang perguruan tinggi. Selain itu di waktu senggang responden dan orang tua mendiskusikan rencana masa depan di perguruan tinggi, remaja pun merasa senang menghabiskan waktu bersama orang tua membicarakan persyaratan pendidikan lanjutan. Remaja juga merasa lebih nyaman menceritakan kebingungan pemilihan jurusan di perguruan tinggi dengan orang tua serta remaja merasa orang tuanya mendengarkan keluhan-keluhan ketika menjalankan rencana pendidikan yang telah disusun. Item-item yang disebutkan tersebut memiliki keterkaitan dengan 
kejelasan orientasi masa depan bidang pendidikan remaja di kota Bandung.

Orang tua yang memperlihatkan kedekatan dengan remaja, memberikan perhatian dan sering mendiskusikan tentang masa depan remaja di masa depan berdampak terhadap kejelasan orientasi masa depan remaja pendidikan. Orang tua yang menghargai pendapat anak, tidak memutuskan pilihan jurusan di perguruan tinggi secara sepihak akan mendukung kejelasan orientasi masa depan bidang pendidikan

\section{Simpulan dan Saran}

Dari hasil penelitian dapat ditarik kesimpulan bahwa pola relasi orang tuaremaja yang memiliki keseimbangan/ balanced pada dimensi adaptabilitas dan kohesi memiliki pengaruh yang lebih besar dengan kejelasan orientasi masa depan di bidang pendidikan pada remaja di kota Bandung. Keseimbangan pola relasi orang tua-remaja yang balance memiliki kemungkinan sebesar 16,181 (1/0,068) kali untuk memiliki OMD pendidikan yang jelas dibandingkan dengan keseimbangan pola relasi orang tua-remaja yang unbalance. Keseimbangan pola relasi orang tua-remaja yang balance memiliki kemungkinan sebesar 2,088 $(1 / 0,479)$ kali untuk memiliki OMD pendidikan yang jelas dibandingkan dengan keseimbangan pola relasi orang tua-remaja dengan kategori mid range. Selain itu, sebagian besar remaja di Kota Bandung telah memiliki OMD pendidikan yang jelas. Keluarga balanced atau seimbang, memiliki keahlian berkomunikasi yang lebih positif. Ini berarti bahwa orang tua dalam berelasi yang memiliki keseimbangan antara kohesi dan adaptabilitas mampu mengajak remaja untuk berdiskusi berkaitan dengan orientasi masa depan bidang pendidikan, serta remaja akan lebih terbuka menyampaikan permasalahannya.

Adapun saran-saran yang dapat diajukan kepada siswa kelas XII sebagai responden diharapkan agar dapat menjalin komunikasi dengan orang tua berkaitan dengan kelanjutan pendidikan di masa depan seperti berdiskusi tentang kemungkinan pilihan jurusan di perguruan tinggi, menceritakan kesulitan dan hambatan dalam mencapai tujuan pendidikan lanjutan di perguruan tinggi. Kepada Guru Bimbingan dan Konseling agar membuat kegiatan layanan bimbingan klasikal yang bersifat preventif bagi orang tua untuk menjelaskan tentang pentingnya membangun relasi yang positif antara orang tua dengan remaja. Kepada peneliti selanjutnya yang tertarik untuk meneliti pola relasi orang tua-remaja dan orientasi masa depan bidang pendidikan sebaiknya memperhatikan beberapa hal seperti keadaan sampel penelitian yang harusnya homogen agar variasi mengenai latar belakang sampel dapat terkontrol. Selain itu penelitian ini dapat dikembangkan untuk melihat pengaruh tiap tipe relasi pada orientasi masa depan dan minatnya dalam menempuh pendidikan tinggi mendatang.

\section{Daftar Pustaka}

Agustian., \& Ginanjar. A. 2001. ESQ : Emotional Spiritual Quotient Berdasarkan Rukun Iman dan 5 Rukun Islam. Jakarta: Arga Wijaya Persada.

Ambari, P. K. M. 2010. Hubungan Antara Dukungan Keluarga Dengan Keberfungsian Sosial Pada Pasien Skizofrenia Pasca Perawatan di Rumah Sakit. Semarang: Skripsi Fakultas Psikologi Universitas Diponegoro.

Fischer, G. 1998. Conceptual frameworks and innovative computational environments in support of self directed and lifelong learning. University of Colorado. Boulder.

Kaplan, R. M., \& Sacuzzo, P. D. 1993. Psycological Testing Principles, Aplication, and Issue. California: Broks/Cole Publishing Company. 
Kuncoro,. \& Mudrajad M. 2006. Regresi Logistik \& Diskriminan, Fakultas Ekonomi \& Pascasarjana UGM.

Locke dan Latham, (1990). A Theory of Goal Setting and Task Performance, Prentice Hall, New Jersey.

Martha, Y. 1991. Dukungan orang tua terhadap keputusan karir remaja dengan status keputusan karir. Jurnal Phronesis, vol. 1.

McCabe, K. M., \& Barnett, B. 2000. The Relation between Familial Factors dan Futur Orientation of Urban, African American Sixth Grader. Journal of Child and Family Studies, Vol. 9. No.4.

Nurmi, J.E. 1989. Adolescent Orientation to The Future: Development of Interest and Plans and Related Attributions and Affect, in the LifeSpan Context. Hensinski: Societas Scientiarum Fennica.

Nurmi, J.E. 1991. How Do Adolescent See Their Future? A Review of The Development of Future Orientation and Planning. Helsinski: Academik Press, Inc.

Nurmi, J.E. 1994. The Development of Future Orientation in a Life Span Context. In Zaleski, Z. (Ed), Psychology of Future Orientation (pp. 63-67). Lublin: Scientific Society of The Catholic University of Lublin.

Olson, D.H. 2000. Circumplex model of marital and family systems. Journal of Family Therapy, 22, 144-167.

Olson, D.H., Russell, C.S. \& Sprenkle, D.H. 1989. Circumplex Model: Systemic assessment and treatment of families. New York: Haworth Press.

Olson, D.H., McCubbin, H.I., Barnes, H., Larsen, A., Muxen, M. \& Wilson, M. 1991. (Second Edition). Families: what makes them work. Los Angeles: SAGE Publishing.
Olson, D.H. 1993. Circumplex Model of Marital and Family Systems. In F. Wals (Ed.), Normal Family Processes. (2nd Ed.). New York: Guilford Press.

Sangadji. H. 2010. Hubungan antara Relasi Remaja-Orang Tua dengan Orientasi Masa Depan di Bidang Pendidikan Siswa SMA Kelas II di Ternate. (Tesis tidak diterbitkan) Fakultas Psikologi Universitas Padjajaran, Bandung.

Santrock, J.W. 2003. Life Span Development. Pekembangan Masa Hidup (terjemah: Achmad Chusairi \& Juda Damanik). Jakarta: Erlangga.

Santrock, J.W. 2010. Adolescence. North America: McGraw-Hill.

Sarafino, E. P. 2006. Health Psychology: Biopsychosocial Interactions. 5th. USA: John Wiley and Sons.

Sugiyono. 2011. Metode Penelitian Bisnis (Pendekatan Kuantitatif, Kualitatif, dan $R \& D)$. Bandung: Alfabeta.

Wibowo, S. M. 2004. Studi Mengenai Relasi Remaja di Lingkungan Keluarga dan Teman Sebaya serta Hubungannya dengan Komitmen, Penilaian Diri, dan Eksplorasi pada Identitas Domain Kerja. (Disertasi tidak dipublikasikan). Fakultas Psikologi Universitas Padjajaran, Bandung. 
Psympathic, Jurnal Ilmiah Psikologi Desember 2016, Vol. 3, No. 2, Hal: 261 - 280 